\title{
СТУДЕНТСЬКА НАУКОВО-ДОСЛІДНА РОБОТА ЯК КОМПОНЕНТ РЕАЛІЗАЦІЇ СТУДЕНТОЦЕНТРОВАНОГО ПІДХОДУ В ОСВІТНЬОМУ ПРОЦЕСІ
}

\author{
I. Horbachevsky Ternopil National Medical University \\ STUDENTS' SCIENTIFIC RESEARCH AS A COMPONENT OF THE \\ IMPLEMENTATION OF STUDENT-CENTERED APPROACH IN THE \\ EDUCATIONAL PROCESS
}

\begin{abstract}
Анотація. Аналіз наукових і навчально-методичних публікацій вітчизняних та зарубіжних авторів, а також власного досвіду керівництва науковими роботами студентів, доводить необхідність залучення здобувачів магістерського рівня вищої освіти за спеціальністю 226 «Фармація, промислова фармація» до набуття додаткових знань, вмінь і навичок у процесі здійснення студентської науково-дослідної роботи (СНДР). Активна участь здобувачів вищої освіти в СНДР розглядається як важлива складова студентоцентрованого підходу в організації їх належної підготовки до майбутньої професійної діяльності, при якій студент має можливість самостійно обирати, серед запропонованих, саме той напрям наукового пошуку, який йому найбільше імпонує. Виокремлено найсуттєвіші компоненти успішної реалізації СНДР, яка сприяє розширенню світогляду, набуттю нового емпіричного досвіду та надасть випускнику певну перевагу на сучасному високонкурентному ринку праці. Участь у міжнародних наукових форумах також стимулює вдосконалення студентами-гуртківцями знань англійської мови як загальновизнаного засобу міжнародного спілкування. Висвітлено необхідність популяризації серед студентів сучасних досягнень фармацевтичної науки, що покладає велику відповідальність на наукових керівників щодо проведення належної роз'яснювальної роботи. Висловлено припущення, що сам викладач, який є науковим керівником СНДР, повинен безперервно розвиватись як науковець і бути відповідним наочним прикладом для студентів, зокрема: мати належний рівень публікаційної активності у рецензованих фахових виданнях, систематично оприлюднювати результати експериментальних досліджень, брати участь у наукових форумах різних рівнів, міжнародних наукових проектах та грантових дослідженнях. Заслуговує уваги використання елементів дистанційного формату комунікації, який було запроваджено через пандемію COVID-19, для оптимізації СНДР вже після завершення дії карантинних обмежень.
\end{abstract}

Ключові слова: студентська науково-дослідна робота; наукова робота студентів в умовах карантину; фармація.

Abstract. Analysis of scientific and educational publications of the Ukrainian and foreign authors, as well as author's own experience in managing of the student scientific activities in the pharmaceutical field, proves the importance of involving applicants in higher education in 226 «Pharmacy, Industrial Pharmacy» scecialty to acquire additional skills of student scientific research. The active involvement of students to the scientific research is regarded as an important component of a student-centered approach at the organization of their high quality training for future professional activities. It means that student has the opportunity to choose independently the most suitable direction of scientific research. There were highlighted the most significant components of the successful implementation of the students' scientific work, which contributes to the expansion of worldview, gaining empirical experience and will provide a certain advantage in today's highly competitive labor market. Participation in international scientific forums stimulates the improvement of students' knowledge of English as a universal instrument of international communication. The necessity of popularization of modern achievements of pharmaceutical science among students was emphasized. It places the great responsibility on scientific supervisors. The scientific superviser himself should continuously work on his progress in science and be a good example for students, in particular: have the appropriate level of publishing activity in peer-reviewed journals, systematically report the results of experimental research at scientific forums of various levels, participate in the international research projects and grants. Some elements of the online communication due to pandemic COVID-19 worth to be used for the optimization the students' scientific research after the end of quarantine restrictions.

Key words: students’ scientific research; peculiarities of the scientific work in a quarantine; pharmacy.

Вступ. Із набуттям чинності Закону України «Про вищу освіту» [3] розпочався новий етап реформування вітчизняної системи освіти, у тому

(c) М. I. Шанайда числі запровадження досвіду передових світових університетів. Реалізація компетентнісного підходу в освітньому процесі передбачає, що прогрес суспільства значною мірою залежить від належно- 
го рівня кваліфікації фахівців - зокрема, у галузі охорони здоров’ я, і визначає необхідність переходу від освіти, яку фахівець отримує один раз на все життя, до набуття необхідних компетентностей, які дають змогу безперервно удосконалювати професійні вміння і навички відповідно до викликів сьогодення [5, 8].

Залучення здобувачів вищої освіти до студентської науково-дослідної роботи (СНДР) є невід'ємною складовою студентоцентрованого підходу до організації навчального процесу, і дає можливість реалізувати ідею, згідно з якою здобувач вищої освіти є суб’єктом освітнього процесу, а не його об’єктом [4]. Такий підхід передбачає стимулювання мотивації студентів та забезпечення відповідних умов, які дають змогу максимально розкрити їхній творчий потенціал через впровадження індивідуальних напрямів в освітньому процесі. Визначено [1, 9], що дослідницький досвід здобувачів вищої освіти сприяє розвитку їхнього творчого потенціалу, усвідомленню цінності наукових досліджень, формуванню цілеспрямованості та мотивації для особистісного розвитку.

Пандемія COVID-19, у зв' язку із загальнодержавними карантинними заходами, призвела до запровадження дистанційної форми навчального процесу $[2,4,5]$. Подолано немало викликів, у тому числі стосовно ефективного проведення СНДР, зважаючи на реалії сьогодення.

Мета статті - аналіз досвіду ефективної організації СНДР у середовищі майбутніх фахівців фармацевтичної галузі та визначення її особливостей в умовах дистанційного навчання.

Теоретична частина. Як показав аналіз болгарських науковців, 87 \% студентів-фармацевтів медичного університету у м. Софія (Болгарія) були зацікавлені у проведенні наукових досліджень, які не передбачені навчальним планом їхньої підготовки, і висловили сподівання, що це стане у пригоді в їх професійній кар’єрі [21]. Американські студенти фармацевтичних коледжів висловили думку про те, що дослідницький досвід покращить їхню здатність незалежно мислити і працювати [19].

Значна частина опитаних студентів-фармацевтів Сіднейського університету (Австралія) [23] висловила припущення про те, що їхнє залучення до наукових дослідницьких проектів було б корисним з точки зору формування важливих компетентностей, проте майже половина вважала їх складними для виконання i не була впевнена, що зможе їх освоїти. Студенти американських коледжів визна- ли, що такий досвід є дуже актуальним у разі обрання кар’єри академічного дослідника і подальшого здобуття наукового ступеня у галузі фармації [17].

Al-Arifi [11], який проводив опитування серед 223 студентів Королівського саудівського університету, зробив таке узагальнення: участь студентів в академічних дослідженнях на додипломному етапі підготовки сприяє формуванню більш висококваліфіковних фахівців у галузі охорони здоров’ я. Більше третини студентів вважали, що участь у дослідницьких проектах сприятиме їхньому успішному просуванню в професійній кар’єрі. 73,6 \% опитаних стверджували, що проведення наукових досліджень взагалі варто ввести до навчального плану підготовки студентів як обов'язковий компонент освітньої програми підготовки магістрів фармації [11], адже у ході СНДР є можливість навчитись аналізувати наукову літературу та писати власні публікації оглядового і дослідницького характеру, узагальнювати та інтерпретувати отримані дані. Студенти окремо відмічають [22], яким важливим є досвід вчитися працювати в команді, а також відчувати задоволення від власного професійного росту і досягнень. Разом $з$ тим, студентів трохи хвилює той момент, що вони не матимуть вдосталь часу на підготовку до занять, якщо будуть активно залучені до наукової роботи [22]. Серед недоліків участі у СНДР було відмічено, що це часозатратні заняття. У цьому випадку дуже суттєвою є роль належного наставництва з боку викладачів, які залучені до керівництва науковою роботою студентів [10]. Студентам варто наголошувати, що участь у СНДР збільшить їхній емпіричний досвід, розширить світогляд та надасть переваги на сучасному висококонкурентному ринку праці [13].

Як відмічають Miller та Jangula [18], існує певна упередженість студентів фармацевтичних факультетів у США стосовно того, що участь у наукових дослідженнях важлива лише для тих, хто планує надалі обрати кар’єру університетського науковця. Getov та співавт. [21] встановили, що серед болгарських студентів лише близько 20 \% зацікавлені у подальшій науковій кар’єрі в університеті, i, зокрема, навчанням в аспірантурі. У зв’язку з цим, дослідники наголошують на необхідності збільшувати привабливість обрання академічної кар’єри для студентів-старшокурсників для того, щоб отримати висококваліфіковані науково-педагогічні кадри у перспективі.

Серед можливих шляхів актуалізації СНДР Nykamp та співавт. [20] виокремлюють наявність 
якісних наукових публікацій у рецензованих наукових журналах, що може привернути увагу студентів до значимості таких досліджень й обрання в майбутньому кар'єри академічного дослідника. Відзначено, що публікації наукових керівників у високорейтингових міжнародних наукових журналах теж сприяють належній мотивації студентів та відкривають можливості отримати необхідний досвід безпосередньо від наставника [11, 21].

Багато авторів публікацій [13, 14, 18, 20-23] наголошують на тому, яку суттєву роль відіграє проведення викладачами роз’яснювальної роботи серед студентів-фармацевтів щодо того, яке значення у перспективі може мати участь у наукових дослідженнях - зокрема, оволодіння навичками роботи у лабораторіях фармацевтичного профілю, оформлення отриманих даних та їх оприлюднення у вигляді публікацій статей, тез доповідей чи виступів на конференціях. Студенти знайомляться із різновидами публікацій, вникають в етапи публікаційного процесу: оформлення статті, її подання до редакції, процеси рецензування та прийняття до друку, а також $з$ рейтингами і квартилями журналів, їхньою індексацією в наукометричних базах даних тощо.

Важливо, що можливість участі у наукових форумах різних рівнів в Україні та за кордоном, а також у конкурсах наукових робіт, дає змогу учасникам СНДР розширити світогляд та набути цінні навички наукової комунікації. Визнання здобутків початківця науковою спільнотою демонструє цінність проведення досліджень і самого науковця як особистості. Окремо слід відмітити, що участь у міжнародних наукових форумах стимулює вивчення і вдосконалення знань англійської мови як загальновизнаного засобу міжнародного спілкування.

Висвітлена вище думка про необхідність популяризації серед студентів сучасних досягнень фармацевтичної науки покладає велику відповідальність на наукових керівників [4, 5], адже СНДР сприяє науковому пізнанню та зумовлює теоретичне осмислення (чи навіть переосмислення) світу, який їх оточує. Lucas та співавт. [16] у висновках свого дослідження відмітили, що перспектива оволодіння новими веб-програми (наприклад, такими, як AcaWriter) також може викликати посилення інтересу в студентів до наукової роботи.

В умовах сьогодення працівники університетів усвідомлюють необхідність брати участь у грантових дослідженнях, що забезпечують фінансову підтримку для проведення експериментальних робіт [15]. Відсутність грантових досліджень ви- кликає проблему недостатнього фінансування наукових проектів, а отже, і закупівлі необхідного обладнання, реактивів тощо [15]. Поступове зростання досвіду з підготовки та отримання грантів в університетах, загалом, також позитивно вплине і на можливості здійснення експериментальних досліджень у рамках СНДР [14]. Отримання грантової підтримки доводить актуальність і затребуваність певного напряму наукових досліджень, а також цінність юного науковця як дослідника.

На основі аналізу власного досвіду керівництва СНДР було зроблено висновок про те, що основну увагу студентів варто спрямовувати на вирішення завдань, які мають проблемний характер. Доцільним $є$ формування чіткого індивідуального напряму діяльності з метою оптимальної організації наукового пошуку літературних джерел та виконання експериментальних досліджень. Наприклад, у галузі фармакогностичних досліджень варто наголошувати на доцільності вивчення саме неофіцинальних видів лікарських рослин, які не входять до вітчизняної та жодної із світових Фармакопей, проте, за даними народної медицини, мають значний терапевтичний потенціал [7, 12]. У процесі пошуку перспективних для фітохімічних досліджень видів рослин досить ефективним є використання філогенетичного методу, який передбачає, що близькі в ботанічному відношенні види і роди рослин мають близький хімічний склад, i, відповідно, подібну фармакологічну дію. Все це, завдяки вивченню неофіцинальних видів зі споріднених таксонів, у майбутньому сприятиме розширенню асортименту рослинної сировини та фітозасобів наукової медицини. Для прикладу, пошук перспективних об’єктів дослідження для студентів закріпленої за мною дослідницької групи проводимо серед видів родини Глухокропивові, які $\epsilon$ філогенетично спорідненими 3 офіцинальними видами - мелісою лікарською, шавлією лікарською, м’ятою перцевою, материнкою звичайною тощо.

Аналіз іншомовних наукових першоджерел та підготовка власних публікацій англійською мовою [12] дає змогу учасникам СНДР відчути себе приналежними до світової наукової спільноти. У процесі пошуку джерел наукової літератури стимулюю студентів використовувати, насамперед, міжнародні наукометричні бази даних - такі, як PubMed, Scopus, WoS, Crossref тощо. Навчаю розрізняти якість наукових журналів за ключовими наукометричними показниками: рівнем цитувань, індексом Гірша тощо. Учасники СНДР спостерігають за послідовними етапами просування поданої 
наукової публікації від подання до прийняття до друку - насамперед, за іï оцінкою рецензентами, які є визнаними фахівцями у галузі.

Безперечним є той факт, що належний рівень володіння англійською мовою дає змогу практично без обмежень брати участь у різноманітних наукових форумах в онлайн-форматі. I, оскільки вже третій рік поспіль вітчизняні студенти третього курсу, які навчаються за спеціальностями галузі знань 22 «Охорона здоров’я», складають єдиний державний тестовий кваліфікаційний іспит, що включає, крім україномовних тестів «Крок 1», також іспит з англійської мови за професійним спрямуванням, активізація залучення студентів-гуртківців до підготовки англомовних статей і доповідей на конференціях сприятиме покращенню їхніх професійних компетентностей.

Варто відзначити, що в Тернопільському національному медичному університеті імені І. Я. Горбачевського MO3 України студенти мають можливість брати участь у двох програмах студентського наукового товариства: «Студентська наука і профорієнтаційне навчання» та «Студент - майбутній фахівець високого рівня кваліфікації». Крім того, для студентів-старшокурсників фармацевтичного факультету, які є здобувачами вищої освіти другого (магістерського) рівня за спеціальністю 226 «Фармація, промислова фармація», досвід участі в СНДР сприяє подальшому успішному виконанню магістерських робіт на завершальному етапі навчання. Все це є важливою передумовою підвищення якості підготовки майбутніх провізорів, які мають змогу набувати знання, вміння і навички наукової роботи за час навчання в університеті.
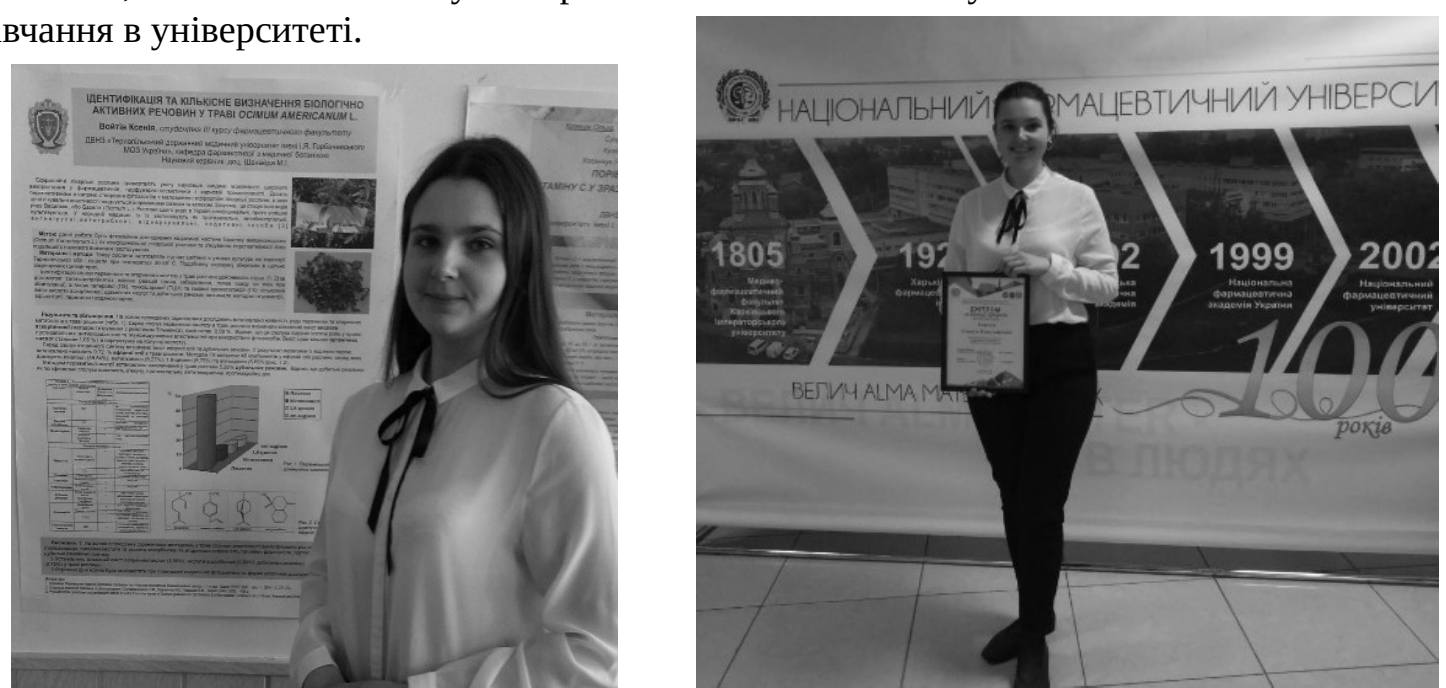

Рис. 1. Презентація Ксенією Войтів стендової доповіді на ХXI Міжнародному медичному конгресі студентів та молодих вчених у 2017 р. (фото зліва) та отримання почесного диплома «За волю до перемоги» за результатами Всеукраїнського конкурсу студентських наукових робіт зі спеціальності «Фармація, промислова фармація» у м. Харкові (фото справа).
Студенти Тернопільського національного медичного університету імені І. Я. Горбачевського МОЗ України мають чудову нагоду презентувати результати виконаної СНДР у вигляді публікації тез, а також стендової чи усної доповіді на Міжнародному медичному конгресі студентів та молодих вчених, який щорічно проводиться на базі закладу вищої освіти у весняний період. Найуспішніші учасники СНДР беруть участь у Всеукраїнському конкурсі студентських наукових робіт зі спеціальності «Фармація, промислова фармація», де є нагода простежити за оцінкою власних здобутків у середовищі десятків найбільш успішних студентів-науковців із різних закладів вищої освіти. 3’являється можливість знайомитись із однодумцями, обмінюватись цінним досвідом чи навіть проаналізувати перспективу обрання для себе подальшої наукової кар’єри. Для прикладу, одна із учасниць студентського наукового гуртка, яка закінчила фармацевтичний факультет нашого університету у 2019 р., 3 другого по п’ятий курси була активно залучена до СНДР під моїм керівництвом. Вона неодноразово презентувала свої наукові доповіді на наукових форумах різного рівня (рис. 1), брала участь у Всеукраїнському конкурсі студентських наукових робіт, а також виконала й успішно захистила дипломну роботу. Таким чином, реалізовується принцип безперервності та різнобічності наукової підготовки здобувачів вищої освіти на додипломному етапі. Не викликає сумнівів те, що отримання нагород, грамот і дипломів додатково сприяє самоствердженню членів СНДР та формуванню їх впевненості у власних силах. 
Загальновідомо, що, у зв’ язку із запровадженням карантинних заходів через пандемію COVID-19, у березні 2020 р. у закладах вищої освіти було запроваджено дистанційну форму навчання [3-5]. Вагомим психологічним фактором дистанційної комунікації, на початковому етапі їі запровадження, була відсутність безпосереднього контакту здобувача вищої освіти із викладачем в аудиторії. Застосування відеозв’язку дало змогу частково вирішити цю проблему, забезпечивши ведення конструктивної бесіди.

Останні півтора року керівництво СНДР, із врахуванням реалій сьогодення, реалізовувалось у режимі он-лайн (рис. 2). Було залучено сучасні інформаційно-комунікативні технології, зокрема: відеоконференції з демонструванням фотографій, відеороликів, Power Point презентацій тощо. Зазвичай у лабораторних умовах неможливо продемонструвати значну кількість методів експерименталь-

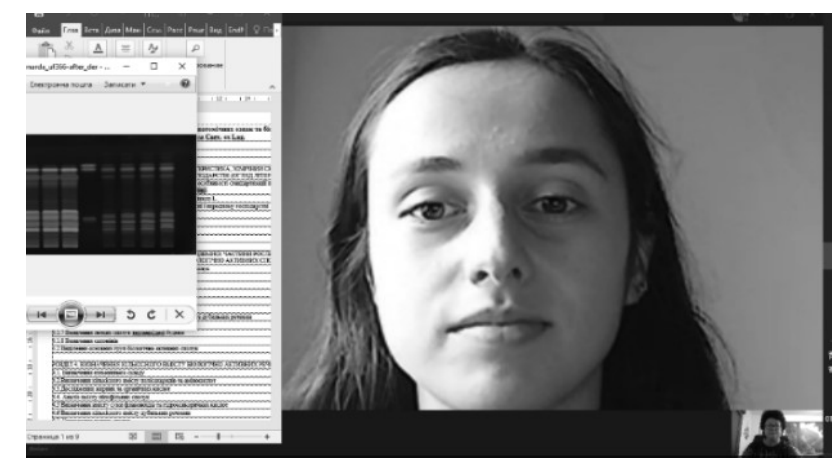

них досліджень одночасно, тоді як режим он-лайн оптимізує це завдання. Студенти ознайомились із принципами і особливостями роботи багатьох приладів, які заплановані до використання в лабораторних умовах, за допомогою відеоматеріалів, наявних у мережі «Інтернет». Оскільки велика кількість наукового інтернет-контенту є англомовною, в учасників СНДР з'явився додатковий стимул до вдосконалення знань із англійської мови. Окрім використання інтернет-ресурсів, як науковий керівник пропоную студентам переглянути відеоматеріали та фотоматеріали власних експериментальних досліджень. Отже, за період від початку запровадження карантину в учасників СНДР з'явилася можливість значно розширити навички роботи 3 науковою літературою за тематикою їхніх фармакогностичних досліджень, а також визначитись із методиками виконання подальших експериментів.

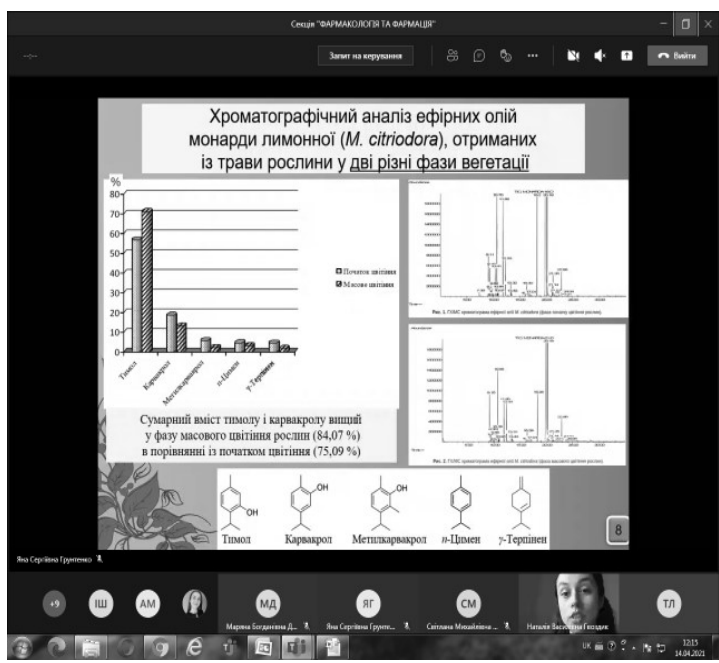

Рис. 2. Реалізація СНДР у режимі он-лайн: консультація за темою наукової роботи студентки Наталії Гвоздик восени 2020 р. (фото зліва) та її усна доповідь на XXV Міжнародному медичному конгресі студентів та молодих вчених у 2021 р. (фото справа).

Використання елементів дистанційного формату для оптимізації СНДР заслуговує уваги і після завершення дії карантинних обмежень. Варто виокремити саме ті позитивні компоненти, які можуть бути інтегровані у звичний формат університетського навчання і наукової роботи. Зокрема, у дистанційному режимі можна проводити семінари на актуальні тематики сьогодення з практично необмеженою кількістю учасників. Так, під час карантину учасникам СНДР запропонувала взяти участь у відеоконференції на актуальну зараз тему: «Можливості застосування фітотерапії у профілактиці та лікуванні COVID-19». Закономірно, що викладач бере безпосередню участь в аналізі, обговоренні та узагальненні підготовлених студентами матеріалів.
Серед переваг онлайн-спілкування слід відзначити те, що вдається залучити більшу кількість студентів, ніж у режимі оф-лайн. Це досить важливо, насамперед, на початкових етапах інформування студентів щодо СНДР. У перспективі можна спробувати практикувати проведення так званих «гібридних» засідань із присутністю в аудиторії частини учасників СНДР та паралельною онлайнтрансляцією на платформі MS Teams, щоб надати дистанційний доступ студентам, які з певних причин не змогли з'явитися на зібрання в аудиторії.

Висновки та перспективи подальших досліджень. Проведений аналіз наукових і навчально-методичних публікацій вітчизняних та зарубіжних авторів, а також власного досвіду ке- 
рівництва студентськими науковими роботами 3 фармакогностичного аналізу лікарських рослин, доводить актуальність та важливість залучення здобувачів магістерського рівня вищої освіти за спеціальністю 226 «Фармація, промислова фармація» до набуття додаткових знань вмінь і навичок у процесі залучення до студентської науково-дослідної роботи. Активна участь у СНДР розглядається як важлива складова студентоцентрованого підходу до організації освітнього процесу. Висловлена думка про те, що сам науковий керівник СНДР повинен безперервно розвиватись як науковець, щоб бути належним прикладом для здобувачів вищої освіти. Науковий керівник, який має належний рівень публікаційної активності у рецензованих фахових

\section{Список літератури}

1. Дащук А. М. Роль науково-дослідної роботи в розвитку творчих здібностей студента / А. М. Дащук, Є. І. Добржанська // Актуальні питання вищої медичної (фармацевтичної) освіти: виклики сьогодення та перспективи їх вирішення : матеріали XVIII Всеукр. наук.-практ. конф. (Тернопіль, 20-21 трав. 2021 р.). Тернопіль: ТНМУ, 2021. - С. 173.

2. Дистанційне навчання - вимушений захід чи вимога часу (на прикладі Тернопільського національного медичного університету імені І. Я. Горбачевського МОЗ України)? / М. М. Корда, А. Г. Шульгай, А. І. Машталір, А. В. Чорномидз // Актуальні питання вищої медичної (фармацевтичної) освіти: виклики сьогодення та перспективи їх вирішення : матеріали XVIII Всеукр. наук.практ. конф. (Тернопіль, 20-21 трав. 2021 р.). - Тернопіль : ТНМУ, 2021. - С. 4-13.

3. Закон України «Про вищу освіту» [Електронний peсурс]. - Режим доступу : http://zakon4.rada. gov.ua/ laws/show/1556-18.

4. Кожем'яка М. О. Організація роботи студентського наукового товариства в умовах дистанційного формату забезпечення освітнього процесу / М. О. Кожем'яка, М. Л. Головаха, Л. С. Лісунов // Медична освіта. - 2021. № 2. - С. 28-34.

5. Роль студентського наукового товариства у вищій медичній освіті: особливості під час пандемії COVID-19 / Т. П. Борисова, Л. І. Вакуленко, А. В. Різник [та ін.] // Актуальні питання вищої медичної (фармацевтичної) освіти: виклики сьогодення та перспективи їх вирішення : матеріали XVIII Всеукр. наук.-практ. конф. (Тернопіль, 20-21 трав. 2021 р.). - Тернопіль : ТНМУ, 2021. - С. 89-91.

6. Студентка ТДМУ відзначена дипломом на Всеукраїнському конкурсі студентських наукових робіт зі спеціальності «Фармація, промислова фармація» [Електронний ресурс]. - Режим доступу : https://www.tdmu.edu. журналах, систематично оприлюднює результати експериментальних досліджень на наукових форумах різних рівнів, бере активну участь у міжнародних наукових проектах та грантових дослідженнях, є добрим наочним прикладом для студентів-науковців.

Вважаємо, що у перспективі більш детального аналізу заслуговує те, наскільки суттєво випливає залучення до підготовки англомовних публікацій і виступів на міжнародних конференціях на покращення професійних компетентностей учасників СНДР. Варто також проаналізувати додаткові можливості використання елементів дистанційного формату для оптимізації СНДР.

ua/?s=\%D0\%B2\%D0\%BE\%D0\%B9\%D1\%82\%D1\%96 \%D0\%B2+\%D0\%BA\%D1\%81\%D0\%B5\%D0\%BD\%D1 $\% 96 \% \mathrm{D} 1 \% 8 \mathrm{~F}$.

7. Хроматографічний аналіз ефірних олій із трави монарди лимонної різних фаз вегетації / М. І. Шанайда, Л. В. Свиденко, Н. В. Гвоздик, Н. І. Гудзь // Фармацевтичний часопис. - 2021. - № 1. - С. 23-32.

8. Черних В. П. Компетентнісний підхід у створенні стандарту вищої освіти спеціальності «Фармація» / В. П. Черних, А. А. Котвіцька, С. В. Огарь // Медична освіта. - 2016. - № 2. - С. 107-109.

9. Шанайда М. І. Студентська наукова робота як засіб формування світогляду майбутніх спеціалістів фармації / М. І. Шанайда // Медична освіта. - 2006. - № 4. C. 58-60.

10. A checklist for the development of faculty mentorship programs / A. V. Law, M. M. Bottenberg, A. H. Brozick [et al.] // American Journal of Pharmaceutical Education. 2014. - Vol. 17, 78 (5). DOI 10.5688/ajpe78598.

11. Al-Arifi M. N. Attitudes of pharmacy students towards scientific research and academic career in Saudi Arabia / M. N. Al-Arifi // Saudi Pharmaceutical Journal. - 2019. Vol. 27 (4). - P. 517-520.

12. Comparative analysis of essential oils of the Monarda L. species cultivated in Ukraine / N. Hudz, M. Białoń, M. Shanaida [et al.] // Contemporary pharmacy: issues, challenges and expectation: International Conference (23rd of October, 2020, Kaunas, Lithuania). - P. 74.

13. Dickinson J. Students as researchers: the effects of employing law students on an empirical research project / J. Dickinson, K. Ferris, J. Marson // The law teacher. - 2021. DOI https://doi.org/10.1080/03069400.2021.1896851

14. Engaging Pharmacy Students in Research Through Near-Peer Training / B. J. Lee, N. J. Rhodes, H. Marc [et al.] // Americam Journal of Pharmaceutical Education. 2017. - Vol. 81 (9). - P. 6340. 
15. Gebremariam E. T. Factors Affecting the Quality of Undergraduate Pharmacy Students' Researches in Ambo University, Ethiopia: A Qualitative Study from Advisors' Perspective / E. T. Gebremariam, D. A. Gadisa // Advances in Medical Education and Practice. - 2021. - Vol. 12. P. 745-754.

16. Implementing AcaWriter as a Novel Strategy to Support Pharmacy Students' Reflective Practice in Scientific Research / C. Lucas, S. S. Buckingham, M. Liu, M. Bebawy // American Journal of Pharmaceutical Education. - 2021. P. 8320. DOI https://doi.org/10.5688/ajpe8320.

17. Methods used by colleges and schools of pharmacy to prepare student pharmacists for careers in academia / S. L. Haines, E. A. Dy-Boarman, K. M. Clifford [et al.] // American Journal of Pharmaceutical Education. - 2017. Vol. 81. - P. 6.

18. Miller D. R. Confirmation Bias as a Factor in Pharmacy Student Assessment of Research Study Quality / D. R. Miller, S. J. Jangula // American Journal of Pharmaceutical Education. - 2019. - Vol. 83 (5). - P. 6754. DOI https://doi.org/10.5688/ajpe6754.

\section{References}

1. Dashchuk, A.M., \& Dobrzhanska, Ye.I. (2021). Rol naukovo-doslidnoi roboty v rozvytku tvorchykh zdibnostei studenta [The role of research work in the development of student creative abilities]. Aktualni pytannia vyshchoi medychnoi (farmatsevtychnoi) osvity: vyklyky sohodennia ta perspektyvy yikh vyrishennia: materialy XVIII Vseukr. nauk.-prakt. konf. - Current issues of higher medical (pharmaceutical) education: current challenges and prospects for their solution: Abstract book of the XVIII AllUkrainian. scientific-practical conference. Ternopil: TNMU [in Ukrainian].

2. Korda, M.M., Shulhai, A.H., Mashtalir, A.I., \& Chornomydz, A.V. (2021). Dystantsiine navchannia vymushenyi zakhid chy vymoha chasu (na prykladi Ternopilskoho natsionalnoho medychnoho universytetu imeni I. Ya. Horbachevskoho MOZ Ukrainy)? [Distance learning - a forced measure or a requirement of time (on the example of I. Horbachevsky National Medical University, Ministry of Health of Ukraine)?]. Aktualni pytannia vyshchoi medychnoi (farmatsevtychnoi) osvity: vyklyky sohodennia ta perspektyvy yikh vyrishennia: materialy XVIII Vseukr. nauk.-prakt. konf. - Current issues of higher medical (pharmaceutical) education: current challenges and prospects for their solution: Abstract book of the XVIII All-Ukrainian. scientific-practical conference. (pp. 4-13) [in Ukrainian].

3. Zakon Ukrainy Pro vyshchu osvitu [The law of Ukraine On Higher Education]. Retrieved from: http://zakon4.rada. gov.ua/laws/show/1556-18 [in Ukrainian].

4. Kozhemiaka, M.O., Holovakha, M.L., \& Lisunov, L.S. (2021). Orhanizatsiia roboty studentskoho naukovoho tovarystva $\mathrm{v}$ umovakh dystantsiinoho formatu zabezpechennia osvitnoho protsesu [Organization of the student scientific society's work in the conditions of remote format
19. Pathways to Improve Student Pharmacists’ Experience in Research / K. S. McClendon, A. M. Bell, A. Ellis [et al.] // American Journal of Pharmaceutical Education. - 2015. Vol. 79, No. (4) 58. DOI https://doi.org/10.5688/ajpe79458.

20. Pharmacy students' participation in a research experience culminating in journal publication / D. Nykamp, J. E., Murphy, L. L. Marshall, A. Bell // American Journal of Pharmaceutical Education. - 2010. - Vol. 74 (3). - P. 47.

21. Study of pharmacy students' attitudes for scientific researches and/or academic career in Bulgaria / I. Getov, H. Lebanova, V. Belcheva, E. Grigorov // Scripta Scientifica Pharmaceutica. - 2014. - Vol. 2. - P. 18-22.

22. The Attitude of Medical and Pharmacy Students towards Research Activities: A Multicenter Approach / A. S. Bhagavathula, D. K. Bandari, Y. G. Tefera [et al.] // Pharmacy. - 2017. - Vol. 11, No. 5(4). - P. 55. DOI 10.3390/ pharmacy5040055.

23. Undergraduate pharmacy students' perceptions of research in general and attitudes towards pharmacy practice research / V. S. Kritikos, S. Carter, R. J. Moles, I. Krass // Int. J. Pharm. Pract. - 2013. - Vol. 21. - P. 192-201.

of the educational process]. Medychna osvita - Medical Education, 2, 28-34 [in Ukrainian].

5. Borysova, T.P., Vakulenko, L.I., Riznyk, A.V., Badohina, L.P., Obolonska, O.Yu., Samsonenko, S.V., ... Porokhnia, N.H. (2021). Rol studentskoho naukovoho tovarystva u vyshchii medychnii osviti: osoblyvosti pid chas pandemii COVID-19 [The role of the student scientific society in higher medical education: features during the COVID-19 pandemic]. Aktualni pytannia vyshchoi medychnoi (farmatsevtychnoi) osvity: vyklyky sohodennia ta perspektyvy yikh vyrishennia: materialy XVIII Vseukr. nauk.-prakt. konf. - Current issues of higher medical (pharmaceutical) education: current challenges and prospects for their solution: Abstract book of the XVIII All-Ukrainian. scientificpractical conference. (pp. 89-91). Ternopil [in Ukrainian].

6. (2019). Studentka TDMU vidznachena dyplomom na Vseukrainskomu konkursi studentskykh naukovykh robit zi spetsialnosti «Farmatsiia, promyslova farmatsiia» [The TSMU student awarded a diploma at the All-Ukrainian competition of student research papers in the specialty "Pharmacy, Industrial Pharmacy"]. Retrieved from: https:// www.tdmu.edu.ua/?s=\%D0\%B2\%D0\%BE\%D0\%B9\%D 1\%82\%D1\%96\%D0\%B2+\%D0\%BA\%D1\%81\%D0\%B5 \%D0\%BD\%D1\%96\%D1\%8F.

7. Shanaida, M.I., Svydenko, L.V., Hvozdyk, N.V., \& Hudz, N.I. (2021). Khromatohrafichnyi analiz efirnykh olii iz travy monardy lymonnoi riznykh faz vehetatsii [Chromatographic analysis of essential oils obtained from the herb of lemon beebalm herb in different phases of vegetation]. Farmatsevtychnyi chasopys - Pharmaceutical Review, 1, 23-32 [in Ukrainian].

8. Chernykh, V.P., Kotvitska, A.A., \& Ohar, S.V. (2016). Kompetentnisnyi pidkhid u stvorenni standartu vyshchoi 
osvity spetsialnosti «Farmatsiia» [Competence approach in creating a standard of higher education in the specialty "Pharmacy"]. Medychna osvita - Medical Education, 2, 107-109 [in Ukrainian].

9. Shanaida, M.I. (2006). Studentska naukova robota yak zasib formuvannia svitohliadu maibutnikh spetsialistiv farmatsii [Student scientific work as a means of forming the worldview of future pharmacy specialists]. Medychna osvita - Medical Education, 4, 58-60 [in Ukrainian].

10. Law, A.V., Bottenberg, M.M., Brozick, A.H., Currie, J.D., DiVall, M.V., Haines, S.T., ... Yablonski, E. (2014). A checklist for the development of faculty mentorship programs. American Journal of Pharmaceutical Education, 17, 78(5). DOI 10.5688/ajpe78598.

11. Al-Arifi, M.N. (2019). Attitudes of pharmacy students towards scientific research and academic career in Saudi Arabia. Saudi Pharmaceutical Journal, 27(4), 517-520. https://doi.org/10.1016/j.jsps.2019.01.015.

12. Hudz, N., Białoń, M., Shanaida, M., Hvozdyk, N.V., Svydenko, L., \& Wieczorek, P.P. (2020). Comparative analysis of essential oils of the Monarda L. species cultivated in Ukraine. Contemporary pharmacy: issues, challenges and expectation: International Conf. Kaunas, Lithuania.

13. Dickinson, J., Ferris, K., \& Marson, J. (2021). Students as researchers: the effects of employing law students on an empirical research project. The law teacher. https://doi.org/ 10.1080/03069400.2021.1896851.

14. Lee, B.J., Rhodes, N.J., Marc, H., Sche M.H., \& McLaughlin, M.M. (2017). Engaging Pharmacy Students in Research Through Near-Peer Training. Americam Journal of Pharmaceutical Education, 81(9), 6340.

15. Gebremariam, E.T., \& Gadisa, D. A. (2021). Factors Affecting the Quality of Undergraduate Pharmacy Students' Researches in Ambo University, Ethiopia: A Qualitative Study from Advisors' Perspective. Advances in Medical Education and Practice, 12, 745-754.
16. Lucas, C., Buckingham, S.S., Liu, M., \& Bebawy, M. (2021). Implementing AcaWriter as a Novel Strategy to Support Pharmacy Students' Reflective Practice in Scientific Research. American Journal of Pharmaceutical Education, 8320. DOI https://doi.org/10.5688/ajpe8320.

17. Haines, S.L., Dy-Boarman, E.A., Clifford, K.M., Summa, M.A., Willson, M.N., Boyle, J.A., \& Peeters, M.J. (2017). Methods used by colleges and schools of pharmacy to prepare student pharmacists for careers in academia. American Journal of Pharmaceutical Education, 81, 6.

18. Miller, D.R., \& Jangula, S.J. (2019). Confirmation Bias as a Factor in Pharmacy Student Assessment of Research Study Quality. American Journal of Pharmaceutical Education, 83 (5), 6754. DOI https://doi.org/10.5688/ajpe6754.

19. McClendon, K.S., Bell, A.M., Ellis, A., Adcock, K.G., Hogan, S., Ross, L.A., \& Riche, D.M. (2015). Pathways to Improve Student Pharmacists' Experience in Research. American Journal of Pharmaceutical Education, 79, (4)58. DOI https://doi.org/10.5688/ajpe79458.

20. Nykamp, D., Murphy, J.E., Marshall, L.L., \& Bell, A. (2010). Pharmacy students' participation in a research experience culminating in journal publication. American Journal of Pharmaceutical Education, 74(3), 47.

21. Getov, I., Lebanova, H., Belcheva, V., Grigorov, E. (2014). Study of pharmacy students' attitudes for scientific researches and/or academic career in Bulgaria. Scripta Scientifica Pharmaceutica, 2, 18-22.

22. Bhagavathula, A.S., Bandari, D.K., Tefera, Y.G., Jamshed, S.Q., Elnour, A.A., \& Shehab, A. (2017). The Attitude of Medical and Pharmacy Students towards Research Activities: A Multicenter Approach. Pharmacy, 11, 5(4), 55. DOI 10.3390/pharmacy5040055.

23. Kritikos, V.S., Carter, S., Moles, R.J., \& Krass, I. (2013). Undergraduate pharmacy students' perceptions of research in general and attitudes towards pharmacy practice research. Int. J. Pharm. Pract., 21, 192-201. 